\title{
The Effectiveness of Business Ethics Implementation in Islamic Economic Law on Islamic Banking
}

\author{
Rini Rahayu Kurniati * \\ Department of Business Administration, Faculty of Administration, University of Islam Malang, Indonesia \\ Fitri Hidayat \\ Department of Civil, Faculty of Law, University of Brawijaya Malang, Indonesia \\ Afifuddin \\ Department of Public Administration, Faculty of Administration, University of Islam Malang, Indonesia
}

\begin{abstract}
Islamic bank is a bank whose activities leave usury issues. Therefore, avoiding interest which is considered usury is one of the challenges for the current Islamic world. The literacy index of Islamic banks in Indonesia has only reached 6.63 percent. The level of literacy or public understanding of Islamic finance is still lower than the level of inclusion. This literacy index shows how much public understanding of Islamic banks including their products and services. Currently, Muslim economists have devoted great attention to finding ways to replace the interest system in banking and financial transactions that are more in line with business ethics and Islamic economic law. Islamic economic law is a sharia economic law system that covers the way and implementation of business activities/ business ethics based on sharia principles. The discussion of business ethics in Islamic economic law is expected to be able to provide understanding to the public about Islamic banks and their effectiveness. The objectives of the research are to (1) find out the business ethics implementation in Islamic economic law at Bank Syariah Mandiri Branch of Sukarno Hatta Malang, and (2) to find out the effectiveness of the business ethics implementation in Islamic economic law at Bank Syariah Mandiri Branch of Sukarno Hatta Malang. The research findings found that business ethics in Islamic economic law is implemented at Bank Syariah Mandiri Branch of Sukarno Hatta Malang by implementing usury elimination, the principle of justice, cooperation, and trust, and conducting legal business transactions (the financing types are based on sharia law). In addition, the business ethics implementation in Islamic economic law at Bank Syariah Mandiri Branch of Sukarno Hatta Malang is considered effective due to the loyal customers based on the increased profits and total assets.
\end{abstract}

Keywords: business ethics, Islamic economic law

DOI: $10.7176 / \mathrm{EJBM} / 11-3-09$

\section{Introduction}

Some of the very underlying aspects in Islamic teachings are aqedah (tawhid), law (sharia), and morals. When someone understands Islamic economics as a whole, then he/ she must understand Islamic economics as a whole from these three aspects. One of the fundamental economic ideas and later a major concern for the development of Islamic economic thought is the connection between tawhid and the problems of economic justice. Economic development is an activity that aims to regulate national household affairs in order to meet all the needs of the population. Thus, development is a process in creating public welfare and educating the nation's life as in the preamble of the 1945 Constitution.

To alleviate the main problems of the economy, a sound and strong banking system is required. The existence of financial institutions, especially the banking sector, occupies a very strategic position in bridging the working capital needs of investment in the real sector with fund owners (Andriansyah, 2009). The main function of the banking sector in macroeconomic policy infrastructure is indeed directed in the context of how to make money effective to increase economic added value. Islamic bank is a bank whose activities leave usury issues (Zainul Arifin, 2012). Therefore, avoiding interest which is considered usury is one of the challenges for the current Islamic world. Currently, Muslim economists have devoted great attention to finding ways to replace the interest system in banking and financial transactions that are more in line with business ethics and Islamic economic law. The Islamic economic law system covers the way and implementation of business activities based on sharia principles. It is called Islamic economic law. Islamic economics is a social science that studies people's economic problems based on sharia principles (Antonio, 2001).

The literacy index of Islamic banks in Indonesia has only reached 6.63 percent. The level of literacy or public understanding of Islamic finance is still lower than the level of inclusion. This literacy index shows how much public understanding of Islamic banks including their products and services (Khairunnisa \& Karseno, 2001). Managing sharia financial institutions must indeed be different from managing conventional financial institutions. Equating it naturally will cause difficulties. The desire to succeed sharia financial institutions must 
start from our deep understanding of the development of business ethics in which discuss the interest elimination, the philosophy of Islamic sharia institutions, the basic principles of the operations of Islamic financial institutions, and its broad impact on people's lives in their relevance to economic development (Soemitra, 2017).

The profit-sharing system in Islamic banks is designed with the aim of fostering togetherness in bearing various business risks and profits between fund owners (shahibul mal) who keep their money in institutions, fund managers (mudharib), and people who need funds or what so-called fund borrowers or fund managers (Margono, 2008). In economic activities, Islam recognizes the term of profit motives. However, the profit motive is bound or limited by moral, social and self-limiting conditions. If these limits are followed and carried out carefully, they will form a harmonious balance between individual and community interests. Based on the description of the understanding of business ethics and basic values that become Islamic economic law systems, including ownership, balance and justice, a research on the is effectiveness of business ethics implementation in Islamic economic law on Islamic banking required.

\section{Materials}

\subsection{Business Ethics in Islam}

Nawatmi (2013) explained that business is an activity that is highly recommended in Islamic teachings. In fact, the Messenger of Allah stated that nine out of ten doors of sustenance were through the trade (hadith). It means that through the trade route, the doors of sustenance will be opened. Thus, the gift of Allah arises from it. Business ethics during the Prophet's time not only laid the foundation for the tradition of the creation of an institution, but also built human resources and moral institutions as supporters and requirements of the institution itself (Muhammad, 2002). Islamic business ethics is a tradition or moral culture related to business or company activities. Institutions will not run well without the application of good morals and ethics. According to Muhammad (2002), Islamic business applies ethics as follows:

a. Usury $($ Riba) Elimination

Although infrastructure had been successfully built, however, the condition of Medina is still not conducive to build the economic sector; especially public economics. The practice of usury at that time had made residents of Medina restless, because the practice of usury seemed to strangle their neck. Public opinion considers that borrowing money from other people accompanied by the determination of usury will increase the loan. This opinion is answered by the Qur'an that this is not true (Surah Ar-Rum: 39). The answer from the Qur'an had not yet obtained a good response from the public. Then, there was a second answer from the Al-Qur'an (Surah AlBaqarah: 275). With the second answer or reprimand from Al-Qur'an, Companions of the Prophet left usury. The usury elimination had been successful in creating conditions that made it possible to grow the economy quickly. During the hijra, Medina City was a poor city, but when the Prophet died, Medina City was a new city that grew and developed to support the surrounding areas.

b. Justice

In every economic policy, the Prophet emphasized justice which not only applies to Muslims, but also applies to other people around Medina. The proof was when the Prophet was asked to set then prices, he refused to do so. It proved that the Messenger of Allah gave up the pricing of natural market forces. Justice in Islamic banking is the provision of profit share that has been agreed upon.

c. Cooperation

The Prophet recommended that every trader always cling to commendable qualities. The profit-sharing system in Islamic banks is designed with the aim of fostering togetherness in bearing various business risks and profits between fund owners (shahibul mal) who keep their money in institutions, fund managers (mudharib), and people who need funds or what so-called fund borrowers or fund managers.

d. Trust

Trust means to stay away from bad qualities which include wrongdoing and deception which take advantage in an improper way. These bad qualities are usually possessed by humans when they enter the business world.

\subsection{Islamics Economic Law}

According to Ali (2008), Islamic economic law is an economic law about the way and implementation of business activities based on sharia principles. Islamic economics is a social science that studies people's economic problems based on sharia principles. Islamic law economics with non-Islamic law economics has fundamental differences. On the one hand, Islamic law economics respects the values of the legal will of the human Creator listed in the Qur'an which is then implemented by humans. At that time, it was implemented by the Prophet at Makkatul Mukarramah and Madinatul Munawarah.

In non-sharia economic law, choice depends on the behavior of each individual. Individuals who do not take into account the behavior requirements that must be possessed by every Muslim will ignore the signs of Islamic law. However, Islamic economic law does not distribute sources that conflict with Islamic legal values.

Ali (2008) also explained that in Islamic economic law, social welfare can be optimized if economic 
resources are allocated in such a way. Islamic economics cannot stand neutral between different objectives. The activity of making and selling intoxicating drinks can be a good activity in a non-sharia economic legal system. However, it is prohibited in the Islamic economic legal system. It is stated in Law No. 3 of 2006 concerning changes to Law No. 7 of 1989 concerning religious justice which was approved by the President of the Republic of Indonesia. The stipulation of this Law has major implications for legislation that regulates property, business and trade widely. Article 49 point 1 clearly states that the religious court has the duty and authority to examine, decide and settle cases in the first level between people who are Muslim in the field of Islamic economics.

Based on this explanation, according to Ali (2008), the Law states that Islamic economics is an act or business activity carried out according to sharia principles, including among others: (1) Islamic banks, (2) Islamic microfinance institutions, (3) Islamic insurance, (4) Islamic reinsurance, (5) Islamic mutual funds, (6) Islamic bonds and medium-term securities, (7) Islamic securities, (8) Islamic financing, (9) Islamic pawnshops, (10) institutional Islamic finance for pension funds, and (11) Islamic business.

The actions or business activities carried out refer to Good Corporate Governance (GCG). GCG is a process of managing the company. According to Machmud and Rukmana (2009), GCG in the banking world is listed in article 1 number 6 Bank Indonesia Regulation (PBI) No.8/4/PBI/2006 concerning the implementation of Good Corporate Governance (GCG) for Commercial Banks. The provision states that GCG is bank governance that applies the principles of transparency, accountability, responsibility, independence and fairness. In the general explanation section, the provisions of PBI No.8/4/PBI/2006 state the following:

a. Transparency is defined as openness in expressing material and relevant information and openness in carrying out the decision-making process.

b. Accountability is the clarity of the functions and responsibilities of the bank that aim to realize effective management.

c. Responsibility is the suitability of bank management with applicable laws and regulations and the principles of sound bank management.

d. Independence is professional management without any influence or pressure from any party.

e. Fairness is justice and equality in fulfilling stakeholder rights that arise based on agreements and applicable laws and regulations.

Melia (2015) mentioned that governance in financial institutions, especially banks, has its own uniqueness compared to governance in non-bank financial institutions. It is caused by the presence of depositors as a group of stakeholders whose interests must be accommodated and maintained. However, the existence of depositor groups in conventional banks does not affect the bank's governance structure too much. The reasons are: (1) the bank has established a guarantee to repay full deposits of customers, (2) the implementation of a guarantee scheme is carried out by both deposit guarantor and government, and (3) there is a strict application of a number of signs in the form of banking prudence provisions by the banking supervision authority. These factors protect the interests of depositor customers against the interests of other stakeholders in the bank. Thus, it reduces the pressure of the governance structure that specifically protects the interests of bank depositors. Some Islamic principles that support the implementation of GCG or governance in the banking world are those Islamic principles which are part of the sharia system as well as Islamic economic law. Sharia system implementation in Islamic banking can be seen from two perspectives which include micro and macro perspectives. Islamic values in the micro perspective require that all funds obtained in the Islamic banking system be managed with high integration and very carefully. These values include the following:

a. Siddiq values ensure that the management of Islamic banks is carried out with morality that upholds the value of honesty. This value reflects that the management of public funds will be carried out by prioritizing methods that are prohibited by sharia, namely those that are dubious and haram.

b. Tabligh value is to continually disseminate and educate the public about the principles, products and services of Islamic banking. In conducting socialization, it should not only prioritize compliance with sharia principles, but also must be able to educate the public about the benefits for users of Islamic banking services.

c. Amanah value strictly keeps the principles of prudence and honesty in managing funds obtained from fund owners (shahibul maal) so that it creates mutual trust between the fund owner and the investment fund manager (mudharib).

d. Fatanah value ensures that bank management is carried out professionally and competitively so as to produce maximum profits in the level of risk set by the bank. It includes services that are full of precision, politeness (ri'ayah), and responsibility (mas'uliyah).

Machmud (2009), in a macro perspective, explains that Islamic values require Islamic banking to contribute to the welfare of society by fulfilling the following things:

a. The rule of zakat conditions the behavior of people who prefer to invest compared to just saving their assets. This is possible since zakat for investment is imposed only on investment returns while zakat for savings is subject to principal savings. 
b. The rule of prohibiting usury promotes equity-based financing and prohibits usury. These non-usury products are expected to be able to encourage the formation of the tendency of people not to be brave in facing risks.

c. The rules of prohibiting gambling or maysir are reflected in the bank activities which prohibit investments that have no connection with the real sector. This condition will shape people's tendency to avoid speculation in their investment activities.

d. The rule of prohibiting uncertainty is prioritizing transparency in transactions and other operations and avoiding obscurity.

Both of these perspectives reflect sharia values in Islamic banking. These values also become characteristics and the business ethics in Islamic economic law that have been explained previously; i.e. the elimination of usury, justice, cooperation and trust. Hasan (2014) mentioned that Islamic economic law in the current Indonesian law system is actually no longer due to the demands of history and big number of Muslim populations as what some people/ parties assume. However, it is also caused by the needs of the wider community after knowing and feeling that the Islamic economic system is very fair and equitable in guarding the welfare of the people preached by the Nation and the Unitary State of the Republic of Indonesia.

From the community need's point of view of, the presence of an Islamic economic system in Indonesia is also caused by the needs of society in general. This is evident from the active involvement of financial institutions and other economic institutions that also accept the presence of an Islamic economic system. The position of Islamic/ sharia economic law will be stronger when it is associated with the country's philosophy and constitution; namely Pancasila and the 1945 Constitution of the Republic of Indonesia. In essence, the Islamic economy is no longer incompatible with Pancasila and the Constitution of the Republic of Indonesia (Hasan, 2014).

\subsection{Islamics Economic Law}

According to Machmud (2009), Islamic banks are a financial institution whose function is to collect public funds and redistribute the funds to the community with the Islamic concept. In Islamic banks, the source of funds comes from core capital and third-party funds, which include deposit funds (wadi'ah). The Islamic banks are run using profit-sharing system and is designed with the aim of fostering togetherness in bearing various business risks and profits between fund owners (shahibul mal) who keep their money in institutions, fund managers (mudharib), and people who need funds or what so-called fund borrowers or fund managers.

Meanwhile, according to Yaya et al (2014), Islamic banking is a bank whose activities refer to Islamic law, does not charge interest, and does not pay interest to customers. Rewards received by Islamic banks as well as those paid to customers depend on the contract and agreement between the customer and the bank. The agreement (contract) contained in Islamic banking must be subject to the terms and harmony of the contract as stipulated in Islamic sharia. The Sharia Banking Act No. 21 of 2008 stated that sharia banking is everything that concerns Islamic banks and sharia business units, including institutions, business activities, and ways and processes in carrying out business activities.

The principles of Islamic banking law according to Hasan (2014) include:

a. It does not allow payment of loans with different values than the predetermined loan value.

b. The fund provider must also share profits and losses as a result of the institution's business that borrows funds.

c. Islam does not allow "earning money from money". Money is only a medium of exchange and not a commodity because it has no intrinsic value.

d. Gharar (uncertainty, speculation) element is not allowed. Both parties must know the profits they will get from a transaction.

e. Investment can only be given to businesses that are not prohibited in Islam. For example, liquor business may not be funded by Islamic banking.

\section{Research Method}

The research sampling method was determined purposively. It determined the informant who is considered to be appropriate intentionally. Data collection was carried out by using interviews and document collection. The data analysis method applied descriptive analysis using qualitative approach.

Research focus:

Business ethics in Islamic economic law which includes the elimination of usury, justice, cooperation and trust in Bank Syariah Mandiri.

Islamic economic law is an economic law that covers the way and implementation of Islamic banking products based on sharia principles. Thus, the discussion of Islamic economic law is inherent in the implementation of transactions in sharia banking products which are sharia business ethics. 


\section{Research Findings and Discussion}

Business ethics in Islamic economic law is implemented at Bank Syariah Mandiri Branch of Sukarno Hatta Malang by implementing usury elimination, the principle of justice, cooperation, and trust, and conducting legal business transactions (the financing types are based on sharia law). In addition, based on the document collection, the business ethics implementation in Islamic economic law at Bank Syariah Mandiri Branch of Sukarno Hatta Malang obtains significant test results due to the loyal customers based on the increased profits and total assets.

\subsection{Business Ethics Implementation in Islamic Economic Law at Bank Syariah Mandiri Branch of Sukarno Hatta Malang}

4.1.1.Elimination of Usury

The elimination of usury is Islamic values which are also business ethics in Islamic economic law that have been applied to Bank Syariah Mandiri. Bank Syariah Mandiri applies a profit-sharing system by not applying interest because interest is usury. Islam, as a religion of revelation, has a standard rule as a guiding principle in carrying out living activities. In addition, for the use and storage of money for the community, they have clear rules. Islamic banking has the same concept as other Islamic financial institutions where the practice of interest and usury is forbidden in the Qur'an and Hadith. The interest system in banks has more harm than benefits. The harms include: (1) accumulation of funds for personal gain, (2) interest is the cost concept given to the next guarantor, (3) channeling funds only to those who are capable, (4) the final guarantor is the community, and (5) the occurrence of gap. Islamic banking has no concept of interest or usury. The concept of Islamic banking confirms that money is not a commodity and is not a profit or usury. This supports Muhammad's theory (2002). 4.1.2 Justice

Business ethics in Islamic economic law states that justice is Islamic values applied by Bank Syariah Mandiri. The principle of justice is manifested in togetherness to bear the risk of profit or loss. The principle of justice in Islamic banking is exemplified in the product of mudharabah contract where the bank as the owner of the capital (sahahibul mal) provides capital to the entrepreneur/ manager (mudharib). Business profits are divided according to the agreement stated in the contract. The profit sharing can be 50\%:50\%, 30\%:70\%, or 40\%:60\%. If a loss occurs, it is borne by the owner of the capital as long as the loss is not due to the negligence of the manager. If the loss is caused due to fraud or negligence of the manager, the manager must be responsible for the loss. This supports Hasan's theory (2014).

4.1.3 Cooperation

Business ethics in Islamic economic law, i.e. cooperation, are Islamic values applied by Bank Syariah Mandiri. This collaboration is manifested in a partnership. Based on the discussion of mudharabah contract, justice is reflected when banks as owners of capital (sahahibul mal) provide capital to entrepreneurs/ managers (mudharib). Business profits are divided according to the agreement stated in the contract. If a loss occurs, it is borne by the owner of the capital as long as the loss is not due to the negligence of the manager. Through mudharabah, both parties working or partnering together will not get interest, but profit and loss sharing from a mutually agreed business. Economic cooperation will create equity, equality, peace and togetherness. This supports Muhammad's theory (2002).

4.1.4 Trust

Business ethics in Islamic economic law, i.e. trust, are Islamic values applied by Bank Syariah Mandiri. The form of trust in Bank Syariah Mandiri is to only conduct business transactions that are halal (the financing types are based on sharia law) and under the supervision of the Sharia Supervisory Board (DPS). Trsut is strongly held by Islamic banking to maintain the stability of the institution. Al-Qur'an (Al-Ashr: 1-3) explains the need to maintain management as a neat structure to achieve the goals of the institution as a manifestation of love for God. Trust is also a social guarantee in which humans can draw closer to God, make and develop net assets, eliminate greed and selfishness. This supports Ali's theory (2008).

\subsection{Effectiveness of the Business Ethics and Islamic Economic Law Implementation at Bank Mandiri}

According to Ahmed (2018), in his research entitled The Effect of Sharia Product Attributes and Islamic Principal Values on Customer Loyalty at Bank Syariah Mandiri Branch of Sukarno Hatta Malang, Islamic principles values influence customer loyalty. This is shown in the calculation obtained from the document analysis that the $t_{\text {-calculate }}$ is 2.495 and $t_{\text {-table }}$ is 2.026 . It means that $t$-calculate value is bigger than $t_{\text {-table }}$ value $(2.495>$ 2.026) with a significance level of $0.017<0.05$. Thus, the test results of Ahmed's research found that the Islamic principles values have a significant effect on customer loyalty. In addition, the value of filling the customer loyalty questionnaire showed high results on a Likert scale standard with criteria: agree as much as $61.25 \%$, strongly agree as much as $21.25 \%$, neutral as much as $5.63 \%$, disagree as much as $9.37 \%$, and strongly disagree as much as $2.5 \%$.

This influence test supports Machmud's theory (2009) who mentioned that business ethics which is a reflection of sharia values in Islamic banking contributes to the welfare of society. In addition, Hasan (2014) 
mentioned that Islamic economic law in the current Indonesian law system is actually no longer due to the demands of history and big number of Muslim populations as what some people/ parties assume. However, it is also caused by the needs of the wider community after knowing and feeling that the Islamic economic system is very fair and equitable in guarding the welfare of the people preached by the Nation and the Unitary State of the Republic of Indonesia which is realized from the loyalty test results that have a significant value. In addition to supporting the theories of Machmud (2009) and Hasan (2014), these research findings also support Permata's research (2014) entitled "Analysis of the Effect of Mudharabah and Musyarakah Financing on the Profitability of Bank Syariah Mandiri” which obtained significant results.

This research also supports Yuli's research (2018) entitled “Analysis of Customer Perceptions of PT Bank Syariah Mandiri Branch of Malang" which found that customer perceptions of PT Bank Syariah Mandiri Malang Branch were influenced by the level of profit sharing provided by banks, personnel attitudes, bank location, and security level.

The above description shows that the business ethics implementation in Islamic economic law at Bank Syariah Mandiri Malang is considered to be effective, which is also supported by the increasing profit and assets. Table 1. Performance of Financial Position Report Description (In Billion IDR) 4.2.1 Asset

\begin{tabular}{|c|c|c|c|c|c|c|}
\hline Description & 2013 & 2014 & 2015 & 2016 & 2017 & Growth 2017:2016 (\%) \\
\hline Asset & 63,965 & 66,956 & 70,370 & 78,832 & 87,940 & 11.55 \\
\hline Productive Asset & 58,947 & 61,766 & 65,087 & 72,968 & 79,737 & 9.28 \\
\hline
\end{tabular}

4.2.2 Profit

Current 2017 profit (Net Profit) IDR 365 billion increased 12.31\% from the current 2016 profit (Net Profit) IDR 325 billion.

(https://www.syariahmandiri.co.id/assets/pdf/annual-report/AR-BSM-2017-Lap-Manajemen-Indonesia.pdf)

\section{Conclusion}

It was concluded that the business ethics implementation in Islamic economic law at Bank Syariah Mandiri Malang is as follows:

The practice of interest and usury is forbidden in the Qur'an and Hadith. The interest system in banks has more harm than benefits. The harms include: (1) accumulation of funds for personal gain, (2) interest is the cost concept given to the next guarantor, (3) channeling funds only to those who are capable, (4) the final guarantor is the community, and (5) the occurrence of gap. Thus, usury elimination is needed.

In the concept of justice, it can create professionalism and competitiveness so as to produce maximum profits in the level of risk set by the bank. It is because justice refers to the same concept of brotherhood for every individual in society. In addition, it must be balanced by economic justice before the law. Without these balances, the concept of justice will be meaningless. By applying the concept of justice, each individual will get their rights in accordance with their respective contributions. Moslem society strictly forbids a Muslim from harming others.

In the concept of cooperation, it can create a better economy and can build equity, equality, peace and togetherness. Cooperation or partnership is a character in the Islamic economic community. Economic cooperation must be carried out in all lines of economic activity both production, distribution of goods, and services. One form of cooperation in Islamic business or economy is qirad or mudharabah. Qirad or mudharabah is cooperation between the owner of capital or money with the entrepreneur who owns the expertise or skills in a business project. Through qirad or mudharabah, the two partners will not get interest, but they get profit sharing for the business project.

In the concept of trust, it will lead to mutual trust between the fund owner and the investment fund manager (mudharib). The trust concept shows that an institution/ Bank Syariah Mandiri can conduct business transactions that are lawful in accordance with sharia principles and under the supervision of the Sharia Supervisory Board (DPS).

Based on the above description, the usury elimination, justice, cooperation and trust which constitutes business ethics in Islamic economic law will create equity, equality, peace and togetherness and realize the effectiveness of Bank Syariah Mandiri Malang followed by the increasing assets and profits.

\section{Suggestion}

The suggestion is if the commendable natures in business ethics in Islamic economic law which covers the elimination of usury, justice, cooperation and trust are always applied, business people or businessman and the community in general will be ready to build themselves in all aspects of good life political, economic, legal and cultural aspects and so forth. Bank Syariah Mandiri Malang is suggested to maintain business ethics in the order of Islamic economic law that they have been done so far because it is proven to show effective results.

The business ethics model in Islamic economic law at Bank Syariah Mandiri can be presented in the 
following picture:

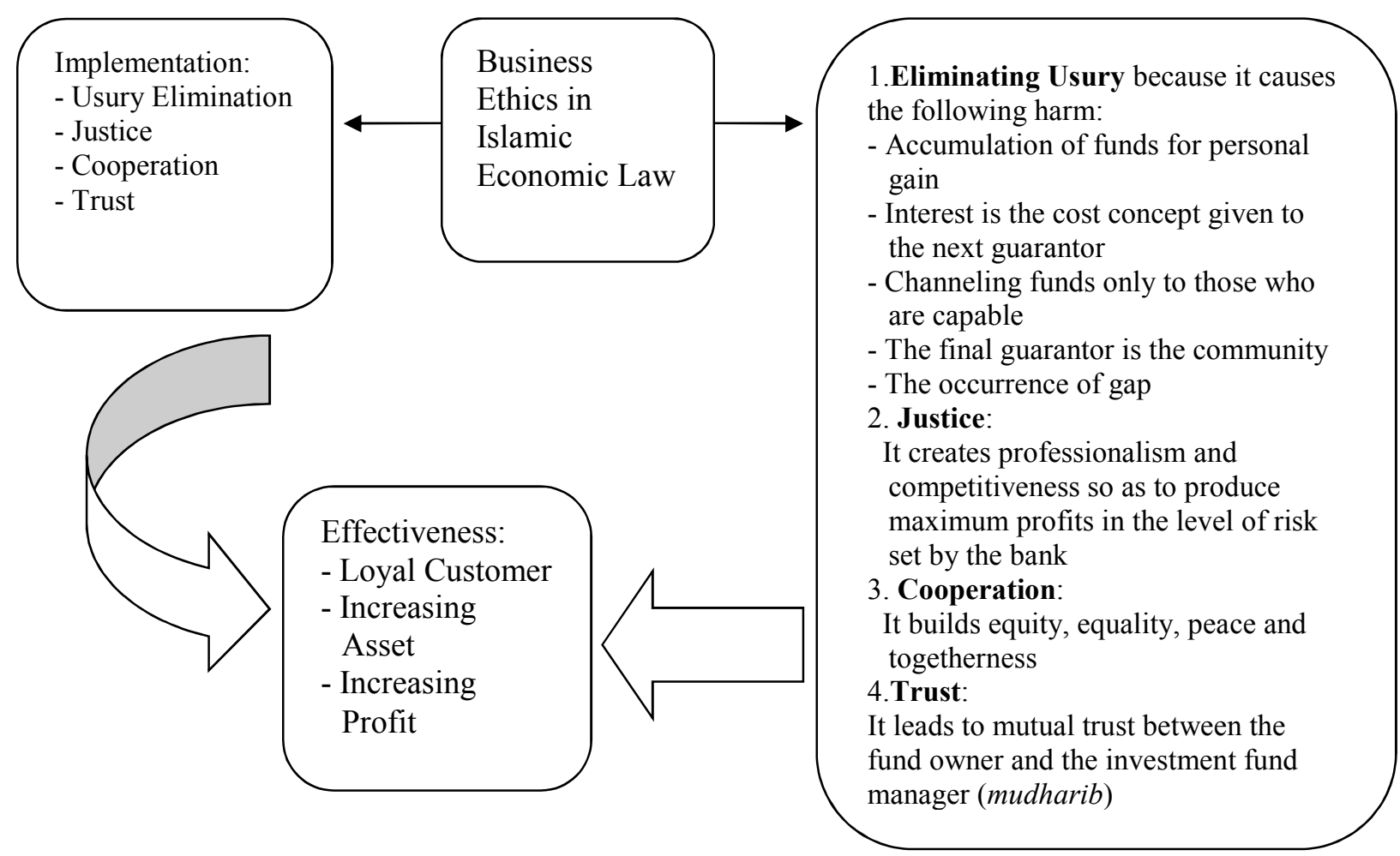

Figure 1. The Business Ethics Model in Islamic Economic Law at Bank Syariah Mandiri

\section{References}

Ahmed, Y.Y. (2018). Pengaruh Syariah Atribut Produk Dan Nilai-Nilai Prinsip Islam Terhadap Loyalitas Nasabah pada Bank Syariah Mandiri cabang Sukarno Hatta Malang. JurnalIlmu Administrasi Bisnis/ Jagabi. Malang. Vol 7. No.3. Tahun 2018. ISSN $2302-7150$

Ali, Z. (2008). Hukum Ekonomi Syariah. Jakarta. Sinar Grafika

Andriansyah, Y. (2009). Kinerja keuangan perbankan syariah di Indonesia dan kontribusinya bagi pembangunan nasional. La Riba, 3(2), 181-196.

Antonio, M. S. I. (2001). Bank Syariah: Dari teori ke praktik. Depok: Gema Insani.

Hasan, N. I. (2014). Perbankan Syariah. Jakarta. GP Press Group

Hasanah, N. (2017). Analisis Pengaruh Pembiayaan Mudharabah dan Musyarakah Terhadap Profitabilitas Pada Bank Syariah Mandiri. Skripsi: Institut Agama Islam Negeri Surakarta.

https://www.dream.co.id/dinar/survei-masih-banyak-orang-ri-belum-pahamkeuangan-syariah-170201p.html

Khairunnisa, D., \& Karseno, A.R. (2001). Preferensi masyarakat terhadap Bank Syariah:: Studi kasus Bank Muamalat Indonesia dan Bank BNI Syariah (Doctoral dissertation, Universitas Gadjah Mada).

Latif, S. (2017). Masih Banyak Orang RI Belum Paham Keuangan Syariah.

Machmud, A. R.(2009). Bank Syariah (Teori, Kebijakan, dan Studi Empiris di Indonesia). Bandung: PT. Gelora Aksara Pratama.

Margono, S. (2008). Pelaksanaan Sistem Bagi Hasil Pada Bank Syariah (Tinjauan Umum Pada BTN Syariah Cabang Semarang)(Doctoral dissertation, Program Pasca Sarjana Universitas Diponegoro).

Melia, A. (2015). Pengaruh Good Corporate Governance terhadap Kinerja Perusahaan pada Sektor Keuangan. Business Accounting Review, 3(1), 223-232.

Muhamad. (2002). Manajemen Bank Syariah. Jogjakarta. UPP. AMP. YKPN

Soemitra, A. (2017). Bank \& Lembaga Keuangan Syariah. Jakarta: Prenada Media.

Yaya, R., Martawireja, A. E., \& Abdurahim, A. (2014). Akuntansi Perbankan Syariah: Teori dan Praktik Kontemporer berdasarkan PAPSI 2013 edisi 2. Salemba Empat.

Yuli, S.B.C. (2018). Analisis Persepsi Nasabah P.T Bank Syariah Mandiri Cabang Malang. https://www.academia.edu/35150151/Analisis_Persepsi_Nasabah_PT._Bank_Syariah_Mandiri_Cabang_M alang

Zainul Arifin, M. B. A. (2012). Dasar-dasar manajemen bank syariah. Pustaka Alvabet. 